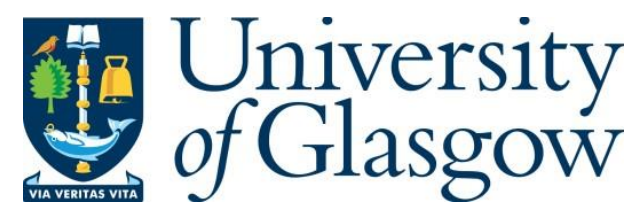

Shakeri, G. and McCallum, C. (2021) Envirofy your Shop: Development of a Realtime Tool to Support Eco-friendly Food Purchases Online. In: CHI EA '21:

Extended Abstract of the 2021 CHI Conference on Human Factors in Computing Systems, 08-13 May 2021, ISBN 9781450380959.

There may be differences between this version and the published version. You are advised to consult the publisher's version if you wish to cite from it.

(C) Association for Computing Machinery 2021. This is the author's version of the work. It is posted here for your personal use. Not for redistribution. The definitive Version of Record was published in CHI EA '21: Extended Abstract of the 2021 CHI Conference on Human Factors in Computing Systems, 08-13 May 2021, ISBN 9781450380959. http://dx.doi.org/10.1145/3411763.3451713.

http://eprints.gla.ac.uk/236398/

Deposited on: 12 March 2021

Enlighten - Research publications by members of the University of Glasgow http://eprints.gla.ac.uk 


\section{Envirofy your Shop: Development of a Real-time Tool to Support Eco-friendly Food Purchases Online}

\author{
Gözel Shakeri \\ University of Glasgow \\ Glasgow, United Kingdom \\ gozel.shakeri@glasgow.ac.uk
}

\author{
Claire McCallum \\ University of Northumbria \\ Newcastle upon Tyne, United Kingdom \\ claire.mccallum@northumbria.ac.uk
}

\begin{abstract}
A third of global greenhouse gas (GHG) emissions are attributable to the food sector, however dietary change could reduce this by $49 \%$. Many people intend to make eco-friendly food choices, but fail to do so at the point-of-purchase. Educating consumers on the environmental impact of their choices during their shop may be a powerful approach to tackling climate change. This paper presents the theory- and evidence-based development of Envirofy: the first eco-friendly e-commerce grocery tool for real shoppers. We share how we used the Behaviour Change Wheel (BCW) and multidisciplinary evidence to maximise the likely effectiveness of Envirofy. We conclude with a discussion of how the HCI community can help to develop and evaluate real-time tools to close intentionbehaviour gaps and ultimately reduce GHG emissions.
\end{abstract}

\section{CCS CONCEPTS}

- Human-centered computing $\rightarrow$ Web-based interaction; Interface design prototyping; Collaborative and social computing devices.

\section{KEYWORDS}

Sustainable HCI; grocery e-commerce; traffic light feedback; ecofriendly; browser extension; digital intervention; Behaviour Change Wheel;

\section{ACM Reference Format:}

Gözel Shakeri and Claire McCallum. 2021. Envirofy your Shop: Development of a Real-time Tool to Support Eco-friendly Food Purchases Online. In CHI Conference on Human Factors in Computing Systems Extended Abstracts (CHI '21 Extended Abstracts), May 8-13, 2021, Yokohama, Japan. ACM, New York, NY, USA, 9 pages. https://doi.org/10.1145/3411763.3451713

\section{INTRODUCTION}

The number one thing individuals can do to substantially lower greenhouse gas (GHG) emissions is to change their diet [62]. Consumers' food choices are responsible for $1 / 3$ of a household's total environmental impact [16], yet the consumption of sustainable food remains low [67]. Some of the least sustainable food choices are even expected to increase. Meat consumption is predicted to

Permission to make digital or hard copies of all or part of this work for personal or classroom use is granted without fee provided that copies are not made or distributed for profit or commercial advantage and that copies bear this notice and the full citation on the first page. Copyrights for components of this work owned by others than ACM must be honored. Abstracting with credit is permitted. To copy otherwise, or republish, to post on servers or to redistribute to lists, requires prior specific permission and/or a fee. Request permissions from permissions@acm.org.

CHI '21 Extended Abstracts, May 8-13, 2021, Yokohama, Japan

(c) 2021 Association for Computing Machinery.

ACM ISBN 978-1-4503-8095-9/21/05 _\$15.00

https://doi.org/10.1145/3411763.3451713 have risen by $72 \%$ from 2000 s to 2030 [55], and dairy production has more than doubled over the past 50 years to meet increasing consumer demands [66]. The eco-friendliness of foods also depends on their transportation method (with airfreight having the greatest environmental impact) [64], as well as the amount of plastic packaging required and extent to which it is recyclable [17]. If we continue to consume food (and drive production) in the same way we do now, the food sector could be responsible for up to $50 \%$ of all global emissions by 2050 [78].

Interestingly, many people do intend to buy environmentally friendly food [92]. Yet, when it comes to the point-of-purchase, their behaviour often does not align with these intentions (known as the "intention behaviour gap" [93]). Even when motivated to make sustainable food choices, the items in shoppers' basket amount to a much higher $\mathrm{CO}_{2}$ value than what is feasible for the planet long-term [62].

Eco-feedback is a promising means of providing education tailored to users' own context and choices [23, 69, 79]. HCI researchers have largely focused on providing eco-feedback on household energy [40,60, 99] and water use [24]. When applied to food consumption, these have addressed only one dimension of their environmental impact (e.g. food waste [47], or organic foods [101]) and not the complexity of a food product's overall environmental impact. Further, such interventions have yet to take advantage of real-time delivery in context. Zapico et al. [101] for example, developed an eco-feedback dashboard on organic food consumption, for use after products had already been purchased, using receipts as data sources. "Just-in-time" [81], "point-of-purchase" [48], and context-based interventions when food shopping [5] can boost the chances of the shopper performing the desired behaviour when it matters most, but have so far been limited to nutrition. Such approaches may be key to addressing the intention behaviour gap in purchasing low impact foods.

Our research focuses on the design space at the point-of-purchase; when food shopping online. Online shopping is increasing rapidly $[13,90]$. Although more environmentally friendly than in-person (due to low transport) [18], there are opportunities to make this increasingly-used medium even more sustainable. Supermarket websites can support real-time interventions; however it is essential that these are theory- and evidence-based to maximise the likelihood they will be effective [11]. Of the few behavioural interventions that have been designed and developed to support sustainable food choices to date, most have lacked a basis in behaviour change theory [34].

This paper outlines the multidisciplinary development of Envirofy, the first real-time web-based tool targeting sustainable food shopping behaviour. We describe how Envirofy was developed 
using both behaviour change theory (Behaviour Change Wheel, $\mathrm{BCW}$ ) [53] and multidisciplinary evidence. By reporting how specific behaviour change techniques (BCTs) were translated and "operationalised" within Envirofy's algorithm and interface, we contribute concrete examples that HCI researchers can draw upon to ensure much-needed future developments in this area are theorybased and likely to be effective. "Early and often" sharing is crucial to promote agile and responsive research [36] that keeps pace with, and takes advantage of, the latest technology [35].

\section{THEORETICAL DEVELOPMENT USING THE BEHAVIOUR CHANGE WHEEL}

\subsection{Steps 1-3. Defining, Selecting, and Specifying the Problem Behaviour}

The first steps of the BCW focus on understanding the problem; in this case environmentally damaging food consumption. Stating the problem in behavioural terms helps to define the target of the intervention [53]. This involves considering first all relevant behaviours by relevant groups (step 1); selecting from these to identify a single target behaviour (step 2); and specifying that behaviour as thoroughly and precisely as possible, using pre-specified prompts provided by the BCW (step 3). The final behaviour is specified in Table 1.

\begin{tabular}{|l|l|}
\hline BCW question & Specification \\
\hline $\begin{array}{l}\text { Who needs to perform the } \\
\text { behaviour? }\end{array}$ & $\begin{array}{l}\text { Individuals who purchase food from supermarkets } \\
\text { online. }\end{array}$ \\
\hline $\begin{array}{l}\text { What do they need to do dif- } \\
\text { ferently? }\end{array}$ & $\begin{array}{l}\text { Select and purchase the most sustainable option } \\
\text { from a range of available food products. }\end{array}$ \\
\hline When do they need to do it? & $\begin{array}{l}\text { When they are choosing food items, at the point- } \\
\text { of-purchase. }\end{array}$ \\
\hline $\begin{array}{l}\text { Where do they need to do } \\
\text { it? }\end{array}$ & $\begin{array}{l}\text { On supermarket websites, using their device, in } \\
\text { locations with internet access. }\end{array}$ \\
\hline $\begin{array}{l}\text { How often do they need to } \\
\text { do it? }\end{array}$ & $\begin{array}{l}\text { Every time they visit the online supermarket web- } \\
\text { site. }\end{array}$ \\
\hline $\begin{array}{l}\text { With whom do they need to } \\
\text { do it? }\end{array}$ & Alone or with members of the same household. \\
\hline
\end{tabular}

Table 1: Specification of the behaviour targeted by Envirofy

\subsection{Step 4. What Needs to Change: Why are People Not Making Environmentally Friendly Food Choices?}

A core step of the BCW is to identify barriers that are currently stopping individuals from doing the specified behaviour. This helps to understand what problems the intervention should solve and how it should work. A narrative literature review was conducted to identify various barriers to purchasing environmentally friendly foods. APEASE criteria [53] were then systematically applied to each barrier to judge whether it was likely to be Affordable; Practical; Effective/cost-effective; Acceptable to users; and Equitable, to target within an online shopping environment. The resulting barriers targeted by Envirofy are reported in Table 2, column 1 . The $\mathrm{BCW}$ provides multiple theoretical tools to interpret and synthesise barriers: (i) COM-B was used to first understand whether, broadly, barriers related to individuals' "Capability", "Opportunity", and/or "Motivation" to engage in a Behaviour (eco-friendly food shopping)
(Table 2, column 2) (ii) The Theoretical Domains Framework (TDF) [52] was then used to describe these barriers in more theoretical detail (Table 2, column 3). In summary, Envirofy targets barriers relating to individual shoppers': knowledge and skills in choosing environmentally friendly foods (i.e. psychological capability); exposure to environmentally friendly foods and opportunity to access these (i.e. physical opportunity); and beliefs relating to "perceived consumer effectiveness" i.e. whether their choices will make an environmental impact (i.e. "reflective motivation").

\subsection{Steps 5-8. What Kind of Intervention?: Intervention Functions, Policy Categories, BCTs and Delivery Modes}

The BCW provides theoretical links between the barriers identified, and the kinds of interventions that are likely to be effective in addressing them. Following this process, Envirofy was designed to target the barriers identified (see step 4) through Education (to improve knowledge on the environmental impact of food choices), Training (to improve skills in selecting products according to environmental labels), Environmental Re-structuring (to improve exposure to and accessibility of environmentally friendly products), and Persuasion (to target beliefs on perceived consumer effectiveness). The delivery mode (i.e. "digital") and policy ("service provision") were decided in advance. To decide which specific behaviour change techniques ("BCTs") to embed in this digital tool we again applied APEASE criteria and consulted the multidisciplinary evidence base, including HCI literature, on ways these had been operationalised. The final BCTs and related evidence are reported for each component in Section 4.

\section{ALGORITHMIC DEVELOPMENT}

\subsection{Apparatus}

One of the main advantages a browser extension provides is that users can interact with the current version of the website. This provides a realistic experience rather than directing users to a simulated website which 1) lacks the polished look and feel of the original website, 2) lacks the vast amount of content the real site provides, or 3) is an in-lab study and lacks real-world fidelity [2]. Browser extensions can be easily installed by the end-user, and content can be injected into existing websites to provide information on top of the natural environment.

Envirofy is optimised for the Chromium browser, covering $85.6 \%$ of internet users in the UK [71]. Envirofy was developed in Javascript. Data collection server was written in Python 3.8.5, and ran on an Ubuntu 18 server in the School of Computing Science at the University of Glasgow. Source code is available on Open Science Framework (Link: https://osf.io/hm9gv/).

\subsection{Algorithm}

Envirofy crawls the detail pages for all products on the current page and extracts Ingredients, Produce $O f$, and Recycling information (Figure 1) to calculate the total environmental impact (TEI). TEI is the function of the $\mathrm{CO}_{2}$ costs which occurred during food production (FP), the packaging life cycle (P), and transport (T): TEI $=\mathrm{FP}+\mathrm{P}+\mathrm{T}$ (based on [98]). As a consumer's food waste cannot be 


\begin{tabular}{|l|l|l|}
\hline Barriers identified in literature & Broad COM-B category & Detailed theoretical description (TDF) \\
\hline $\begin{array}{l}\text { Limited awareness of the association between food } \\
\text { choices and environment [46]. Limited factual knowl- } \\
\text { edge about impact of specific food types [49]. Limited } \\
\text { skills and understanding of eco labels [83, 86]. }\end{array}$ & Capability (psychological) & $\begin{array}{l}\text { Behavioural regulation (i.e. monitoring food choices in relation to their environmen- } \\
\text { tal impact) } \\
\text { Knowledge (i.e. of the environmental impact of food groups and individual products) } \\
\text { Cognitive and interpersonal skills (I.e. in understanding and using environmental } \\
\text { information) }\end{array}$ \\
\hline $\begin{array}{l}\text { Perceived lack of time [9, 14, 59, 63, 72] to use en- } \\
\text { vironmental information and limited availability of } \\
\text { eco-friendly foods [4, 56, 100]. }\end{array}$ & Opportunity (physical) & Environmental Context and Resources \\
\hline $\begin{array}{l}\text { Belief that actions will not have an impact (Perceived } \\
\text { Consumer Effectiveness, PCE) [31, 49,57]. }\end{array}$ & Motivation (reflective) & $\begin{array}{l}\text { Beliefs about consequences } \\
\text { Beliefs about capabilities }\end{array}$ \\
\hline
\end{tabular}

Table 2: Selected barriers Envirofy targets towards purchasing environmentally friendly foods

determined at the point-of-purchase, it is neglected in the equation. The TEI is calculated for 100 grams of the product.

3.2.1 Food Production (FP). The $\mathrm{CO}_{2}$ cost of food production (e.g. environmental impact of growing food) is determined by the ingredients list. On the example of "Sharwoods Green Label Mango Chutney 227G" [82] the ingredients list reads "Sugar, Mangoes (45\%), Salt, Acid (Citric Acid), Spices". The mean $\mathrm{CO}_{2}$ value for each ingredient is extracted from $[3,62]\left(\mathrm{CO}_{2}\right.$ is used as the measure of environmental impact as all publicly available databases provide these data, in contrast to GHG data). As the distribution of ingredients beyond the $45 \%$ mango is not clearly stated, an exponential decay function is applied to determine the composition of the remaining 55\%: $y=a(1-b) * x ; x$ is the number of remaining items in the list, $(1-b)$ is the decay factor, and $a$ is the remaining percentage (e.g. 55\%), and $y$ the amount it contributes to the overall product. Items leading the ingredients list contribute greater towards the final product. If no ingredients list was provided on the product page, the algorithm used the words in the title as a $100 \%$ component (e.g. mango from "Tesco Giant Mango Each").

3.2.2 Packaging $(P)$. The $\mathrm{P}$ value is a function of the plastic's life cycle [17], containing plastic production, recycling, and the waste handling of the packaging [73]. If a food item's packaging consists of recyclable and a non-recyclable components, the $\mathrm{P}$ value represents both life cycles. If the online retailer does not specify the type of plastic (e.g. polypropylene, polystyrene), the average life cycle cost for all plastic [25] is used. The computation of the $\mathrm{P}$ value is based on the assumption that all recyclable plastic will be recycled.

3.2.3 Transport (T). The T value is described as: $y=d * m * w$, where $d$ is the distance travelled, $m$ is the mode of transportation (e.g. lorry, plane), and $w$ is the net weight of the product. From a product's detail page, the list of origin countries is extracted. If there is a single country of origin, the distance between the user and that country's coordinates is calculated in kilometres. Country coordinates are from [12]; and participants' coordinates are retrieved from the Tesco website, as it collects location data. If multiple countries are listed including the UK, it is first checked whether the product is in season in the UK [58]; if true, the UK is assumed to be the country of origin. If however, the product is not in season in the UK or from outside the UK, the average distance from the participant's location to the other countries is calculated.

Transport mode -lorry, train, ship, plane - is determined on the distance of the product from the consumer, and whether that product is perishable (e.g. avocados). Perishable foods are transported by train or plane, and non-perishable and frozen foods are transported by sea or lorry [21]. If a product originates in Europe, non-perishable foods are on average transported to the UK via lorries, and perishable foods via train; otherwise via ship or plane [64]. Keywords such as "perfectly ripe", "frozen", and "dried" help determine the mode of transport, as well as categorisation of products into "fresh" or "cupboard". The net weight of a product is extracted from its detail page.

\section{TECHNIQUES AND THEIR DESIGN WITHIN THE ENVIROFY INTERFACE}

In this section we describe the main components of Envirofy, including the BCTs and intervention functions they support, and multidisciplinary evidence used to inform their design. The final designs or "operationalisations" of BCTs within Envirofy were refined using think aloud methods ( $\mathrm{n}=11,6$ females, age $33.1 \pm 14.5)$ (University of Glasgow Ethics Committee approval number 300190261).

\subsection{Carbon Labelling and Traffic Light Colour Coding}

$B C T$ s: Information about social and environmental consequences; prompts/cues; conserve mental resources. Main function: Education.

Related Work. Carbon labelling encourages consumers towards environmentally friendly purchases [45, 95], through increasing knowledge about food product sustainability [6]. The effectiveness of carbon labelling increases if the item's environmental footprint is explained through its components (i.e. production, transport, and packaging) [28], as more information increases consumers confidence in their decision [75]. Presenting the environmental impact relative to other products, rather than stand alone, allows for comparison between products, which is preferred [32,74]. Research has shown that the use of traffic light colours is effective in communicating a product's environmental performance [29, 88], particularly if combined with carbon labels and especially with environmentally concerned consumers [85].

Envirofy. Four traffic light colour coded labels are displayed under each product - globe (TEI), factory (Food Production), vehicle (Transport), and recycling (Packaging) (Figure 1) - allowing for high level information at a single glance [28]. The display of these four pieces of information encourage consumers to actively compare the environmental performance of products [74]. The threshold values for the traffic light colours are based on [6]. If information for a product's FP, T, or P calculations lacked, the corresponding icons 


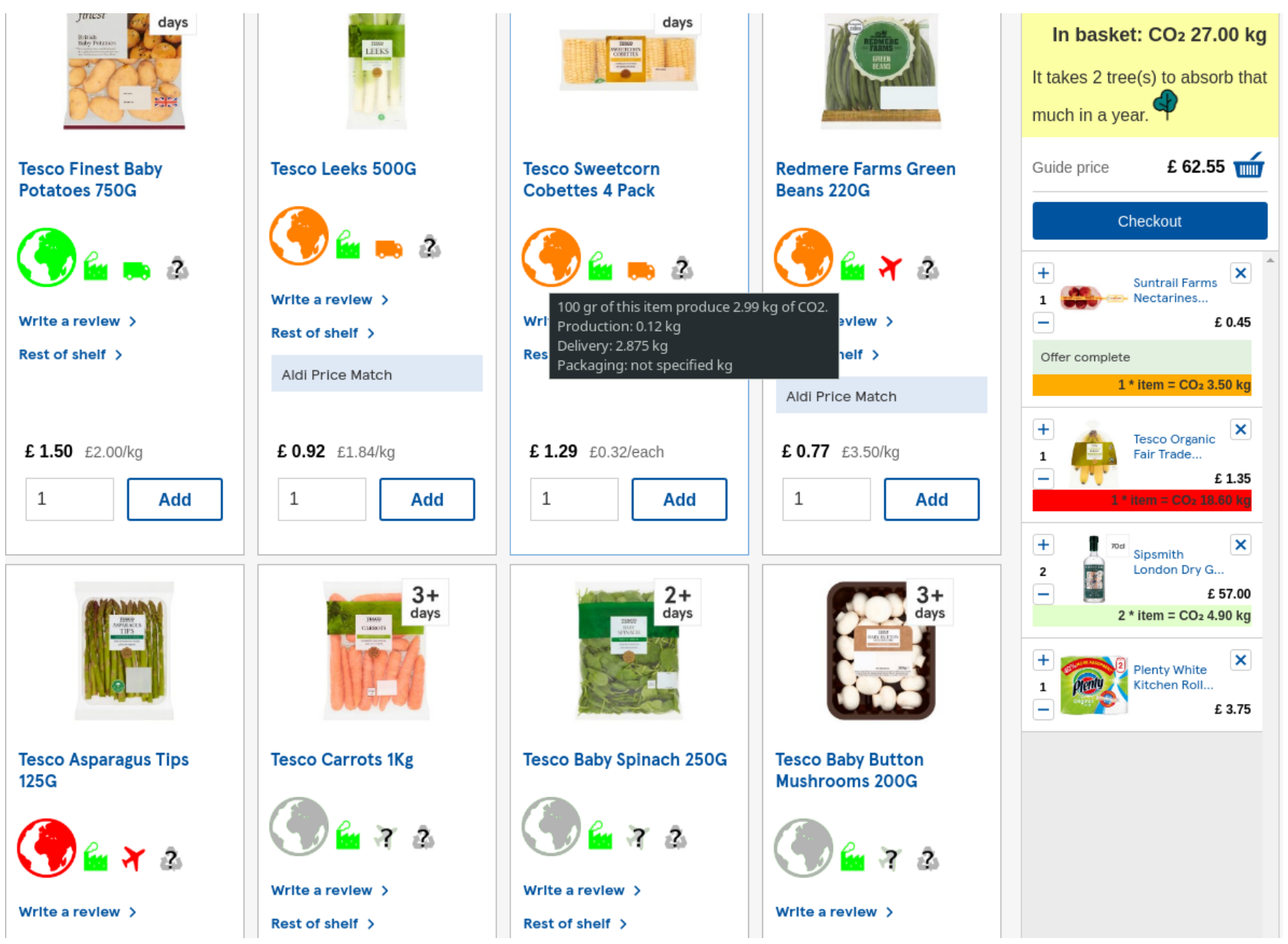

Figure 1: Envirofy's interface for Tesco PLC [65]. The query word was “fresh vegetables”, date 16/07/2020.

were displayed in grey with a superposed question mark (Figure 1). If products lacked data for FP or T, their globe was coded grey. Items in the basket were coloured according to the item's total environmental performance.

\subsection{Ordering Products by Environmental Impact}

BCTs: Prompts/cues; restructuring physical environment; conserving mental resources. Main function: Environmental Restructuring.

Related Work. Consumer choices can be governed by the choice environment [45], and rearranging this environment can engage with consumer's automatic and impulse-driven decision making [15]. This approach helps consumers to make better choices without appealing to reason or forcing certain choices upon them [38]. Shelf arrangement (i.e. accessibility; target foods on higher shelves versus lower shelves) and assortment structure (i.e. availability: offering an assortment of target foods) [89] can be successful in impacting food choices [91]. The essence of such 'nudging' approaches is to change environments in such a way that the better choice becomes a more convenient, attractive, or normal choice [96].

Envirofy. The TEI of a food item determines the display order on the current web page. Items with small TEIs are presented at the top of the page (green globes), and items with increasingly higher impacts are lower on the page (orange or red globes). Items with inconclusive TEIs (grey globes) are appended to the end of the page, penalising the lack of environmental information.

\subsection{Running Total and Presentation of Carbon Footprint Information}

BCTs: self-monitoring of outcomes of behaviour; feedback on outcome of behaviour; information about social and environmental consequences; salience of consequences. Main functions: Knowledge, Training, Persuasion.

Related Work. Supplying consumers with consumption feedback in (near) real-time can change environmental behaviours [94], conditional on a person's environmental attitude [37]. Many consumers, 
however, may not understand or fully appreciate raw carbon footprint information, which can impact its interpretation and application [97]. Information format can influence interpretation; presenting tree equivalents (i.e. the number of trees required to offset a $\mathrm{CO}_{2}$ value) can help people to visualise and provide context to the abstract $\mathrm{CO}_{2}$ value [97].

Envirofy. Real-time feedback on the overall impact of the items currently in the user's basket are displayed. This includes the $\mathrm{CO}_{2}$ value and the number of trees that would need to be planted to offset the current shop.

\subsection{Motivational Prompts and Perceived Consumer Effectiveness}

$B C T s$ : Credible source; information about social and environmental consequences; information about emotional consequences; verbal persuasion about capability; salience of consequences. Main function: Persuasion.

Related Work. Motivational messages, cues, and prompts can increase a consumer's perceived effectiveness, and ultimately impact their purchase of sustainable foods [39]. Motivational messages have been shown to significantly increase perceived competence, engagement, and intentions to shop greener [26, 70, 77] if consumers have knowledge on climate change already [54]. In particular, delivering motivational messages within the context that the desired behaviour could be performed (i.e. shopping) can aid the consumer in adhering to their goals [51].

Envirofy. One of six messages (Appendix A) is displayed at the beginning of each shop via a pop-up box. The aim is to improve perceived consumer effectiveness through messages explaining the impact of a shop from reputable sources (e.g. The Guardian). The messages target specific emotions tied to sustainable consumer behaviour, such as pride and guilt [70], concern [54], where possible focus on gains as opposed to a sense of loss or sacrifice [26], as well as social rather than personal impacts of climate change [77].

\subsection{Partial Information and Active Search}

BCTs: Information about social and environmental consequences; prompts/cues. Main functions: Knowledge, Training.

Related Work. Making partial environmental performance information available to consumers encourages active search for a product's details [43]. This in return increases confidence in their knowledge and decision making and has a stronger impact on consumers' willingness to buy environmentally friendly items [8, 33].

Envirofy. A box with detailed environmental information is presented when a mouse hovers above a product. This includes the TEI per 100 grams of the product, and a decomposition of this value into FP, T, and P values (Figure 1). Thus, the hover box encourages the consumer to compare the products [74] via numerical TEI values. It also provides the consumer with information in a familiar format, since nutrition values (e.g. calories, carbohydrates, protein) are also presented per 100 grams. Finally, the numerical values in the hover box encourage the consumer to actively search [43] a product's detail page (e.g. country of origin).

\section{DISCUSSION}

This paper presents the first real-world tool that helps online grocery shoppers to reduce their dietary carbon footprint by presenting behavioural intervention techniques at the point-of-purchase.

We used BCW “APEASE” criteria (i.e. Affordability, Practicality/Feasibility, Effectiveness, Acceptability, Safety and Equity) [53] to make design decisions, which enabled us to systematically justify and record these. However, evidence (Section 4) to support criteria other than Effectiveness, such as real-world Practicality and Acceptability, was scarce. These criteria relied instead on our own design experience. Social and cultural identity was a significant barrier identified, but not targeted (Table 2), because other barriers were considered to be more Practical and Acceptable to address at the point-of-purchase. We believe that sustainable HCI researchers have a central role in pushing the boundaries of intervention development: targeting the most challenging barriers, innovating novel BCT designs, empirically evaluating these using APEASE criteria, and sharing them to contribute to an evidence base [36] that complements and advances environmental behaviour change theory.

In addition to theory, existing evidence, and our own experience, we consulted potential users using think aloud methods. However, this was only to refine BCT operationalisations (Section 4) once most BCW stages were complete. Showing users concrete operationalisations of BCTs provided us with useful feedback to further optimise Envirofy (e.g. more meaningful visual representation of a shop's carbon footprint such as "planets used") [97] and additional BCTs it could support (e.g. contextualising $\mathrm{CO}_{2}$ values with a target $\mathrm{CO}_{2}$ per person, i.e. goal setting [76]). It may be more challenging to explore potential users' APEASE-related perspectives within earlier stages of the BCW (e.g. the acceptability of abstract theoretical concepts such as "self-monitoring"), however co-design methods should be employed early [68] in any intervention development work.

Beyond front-end development, further algorithmic work is required, and underway, to reduce the carbon footprint of Envirofy itself. Currently, Envirofy crawls the detail pages for each product on the current page, and as users execute on average 30 queries per shop (based on our one-month-long pilot study, $n=6,5$ females, age $31.6 \pm 6.7$ ), this can result in around 4.89 kilograms of $\mathrm{CO}_{2}$ per shop. We aim to mitigate this by crawling all data once and storing $\mathrm{CO}_{2}$ values on our server. This will result in just $0.204 \mathrm{~kg} \mathrm{CO}$ per shop. Thus, when deciding which intervention techniques to design and operationalise, the environmental footprint required (e.g. to provide real-time feedback) should be considered in addition to APEASE criteria.

Envirofy delivers intervention techniques, in real-time, within the context which purchase barriers operate (i.e. the intentionbehaviour gap that occurs when shopping). Envirofy is also uniquely suited to a real-world evaluation in this context, to assess whether it actually changes shoppers' purchases and associated $\mathrm{CO}_{2}$ values (i.e. closes the intention-behaviour gap). This will involve logging this data and randomising users to receive all or no components (Section 4). To further optimise Envirofy, we will also explore who it works for and how it changes behaviour [44], by collecting demographics known to influence eco-friendly food purchases (Appendix B), and 
assessing Envirofy's direct impact on the barriers identified (e.g. on Knowledge and Perceived Consumer Effectiveness, Appendix C). Such real-world evaluations will need to consider the acceptability of collecting shopping data which is perceived as very personal [1]. Overall, the intention-behaviour gap is a widespread problem across several domains of sustainability beyond food choices [19]. The methodological approach and designs reported in this paper should be explored to improve sustainable shopping for a range of online products and marketplaces.

Envirofy supports individual-level behavioural changes, while providing the user with the freedom of choice. During BCW stages 1-3, other stakeholder behaviours were considered, including those of retailers and food producers. The concept of "spillover" (i.e. selecting behaviours that may positively impact others' behaviours) $[53,87]$, suggested that consumers choosing more sustainable foods may drive the market for retailers and food producers to sell and produce sustainable foods. Envirofy supports this by e.g. reordering food items according to their environmental impact, which may incentivise producers to optimise their ranking. Designing for other stakeholders in this space should be explored, however targeting consumers directly may be a relatively quick route to substantially reducing carbon emissions, and buy time needed for large-scale industrial changes, transitions to greener production and supply chains [62], and more eco-friendly policies [84].

\section{CONCLUSION}

To alter the substantial impact of our food choices on the planet, individuals are required to purchase more environmentally friendly food. Envirofy helps to address this requirement by presenting theory- and evidence-based behavioural intervention techniques, at the point-of-purchase, when online shopping. HCI researchers have an important role in designing, developing and evaluating novel behavioural interventions that target sustainable food choices, intention-behaviour gaps in other domains, and ultimately in reducing GHG emissions.

\section{REFERENCES}

[1] Gina M Almerico. 2014. Food and identity: Food studies, cultural, and personal identity. Journal of International Business and Cultural Studies 8 (2014), 1.

[2] Brandon Herbert Baker. 2013. High fidelity website research: using a browser extension to provide a natural environment. Ph.D. Dissertation. Massachusetts Institute of Technology.

[3] Mike Berners-Lee. 2011. How bad are bananas?: the carbon footprint of everything. Greystone Books.

[4] Anders Biel and Ulf Dahlstrand. 2005. Values and habits: a dual-process model Environment, information and consumer behaviour 33 (2005).

[5] Marcela C. C. Bomfim, Sharon I. Kirkpatrick, Lennart E. Nacke, and James R. Wallace. 2020. Food Literacy While Shopping: Motivating Informed Food Purchasing Behaviour with a Situated Gameful App. In Proceedings of the 2020 CHI Conference on Human Factors in Computing Systems (Honolulu, HI, USA) (CHI '20). Association for Computing Machinery, New York, NY, USA, 1-13. https://doi.org/10.1145/3313831.3376801

[6] Florentine Brunner, Verena Kurz, David Bryngelsson, and Fredrik Hedenus. 2018. Carbon Label at a University Restaurant - Label Implementation and Evaluation. Ecological Economics 146 (2018), 658 - 667. https://doi.org/10. 1016/j.ecolecon.2017.12.012

[7] Damian Carrington. 2018. Avoiding meat and dairy is 'single biggest way' to reduce your impact on Earth. https://www.theguardian.com/environment/ 2018/may/31/avoiding-meat- and-dairy-is-single-biggest-way-to-reduceyour-impact-on-earth

[8] Yu-Chen Chen, Rong-An Shang, and Chen-Yu Kao. 2009. The effects of information overload on consumers' subjective state towards buying decision in the internet shopping environment. Electronic Commerce Research and Applications 8, 1 (2009), 48 - 58. https://doi.org/10.1016/j.elerap.2008.09.001
[9] Á Ní Choisdealbha and Peter D Lunn. 2020. Green and Simple: Disclosures on Eco-labels Interact with Situational Constraints in Consumer Choice. Journal of Consumer Policy 43, 4 (2020), 699-722.

[10] Laurie Clarke. 2019. The practical ways to reduce your carbon footprint (that actually work). https://www.wired.co.uk/article/reduce-carbon-footprint

[11] Peter Craig, Paul Dieppe, Sally Macintyre, Susan Michie, Irwin Nazareth, and Mark Petticrew. 2008. Developing and evaluating complex interventions: the new Medical Research Council guidance. Bmj 337 (2008).

[12] Inc. CSG, Computer Support Group and CSGNetwork.Com. 2020. Countries, Capitals, Latitude and Longitude Table. http://www.csgnetwork.com/ llinfotable.html

[13] Rhys Dalgleish. 2021. Internet sales as a percentage of total retail sales (ratio) (\%). https://www.ons.gov.uk/businessindustryandtrade/retailindustry/ timeseries/j4mc/drsi

[14] Elisa De Marchi, Vincenzina Caputo, Rodolfo M. Nayga, and Alessandro Banterle. 2016. Time preferences and food choices: Evidence from a choice experiment. Food Policy 62 (2016), 99 - 109. https://doi.org/10.1016/j.foodpol.2016.05.004

[15] René A. de Wijk, Anna J. Maaskant, Ilse A. Polet, Nancy T. E. Holthuysen, Ellen van Kleef, and Monique H. Vingerhoeds. 2016. An In-Store Experiment on the Effect of Accessibility on Sales of Wholegrain and White Bread in Supermarkets. PLOS ONE 11, 3 (03 2016), 1-8. https://doi.org/10.1371/journal.pone.0151915

[16] Christopher Dey, Charles Berger, Barney Foran, Miles Foran, Rowena Joske, Manfred Lenzen, and Richard Wood. 2007. Household environmental pressure from consumption: an Australian environmental atlas. Sydney University Press.

[17] Aaron Dormer, Donal P. Finn, Patrick Ward, and John Cullen. 2013. Carbon footprint analysis in plastics manufacturing. Journal of Cleaner Production 51 (2013), 133 - 141. https://doi.org/10.1016/j.jclepro.2013.01.014

[18] Gareth Edwards-Jones. 2010. Does eating local food reduce the environmental impact of food production and enhance consumer health? Proceedings of the Nutrition Society 69, 4 (2010), 582-591. https://doi.org/10.1017/ S0029665110002004

[19] Ghina ElHaffar, Fabien Durif, and Laurette Dubé. 2020. Towards closing the attitude-intention-behavior gap in green consumption: A narrative review of the literature and an overview of future research directions. Journal of Cleaner Production 275 (2020), 122556. https://doi.org/10.1016/j.jclepro.2020.122556

[20] Leisa Reinecke Flynn and Ronald E. Goldsmith. 1999. A Short, Reliable Measure of Subjective Knowledge. Journal of Business Research 46, 1 (1999), 57 - 66. https://doi.org/10.1016/S0148-2963(98)00057-5

[21] Time for Change. 2020. CO2 emissions for shipping of goods. https:// timeforchange.org/co2-emissions-for-shipping-of-goods/

[22] Oliver Franklin-Wallis. 2019. 'Plastic recycling is a myth': what really happens to your rubbish? https:/www.theguardian.com/environment/2019/aug/17/ plastic-recycling-myth-what-really-happens-your-rubbish

[23] Jon Froehlich, Leah Findlater, and James Landay. 2010. The Design of EcoFeedback Technology. In Proceedings of the SIGCHI Conference on Human Factors in Computing Systems (Atlanta, Georgia, USA) (CHI '10). Association for Computing Machinery, New York, NY, USA, 1999-2008. https://doi.org/10. 1145/1753326.1753629

[24] Jon Froehlich, Leah Findlater, Marilyn Ostergren, Solai Ramanathan, Josh Peterson, Inness Wragg, Eric Larson, Fabia Fu, Mazhengmin Bai, Shwetak Patel, and James A. Landay. 2012. The Design and Evaluation of Prototype EcoFeedback Displays for Fixture-Level Water Usage Data. In Proceedings of the SIGCHI Conference on Human Factors in Computing Systems (Austin, Texas, USA) (CHI '12). Association for Computing Machinery, New York, NY, USA, 2367-2376. https://doi.org/10.1145/2207676.2208397

[25] Juerg from Time for Change. 2020. Plastic bags and plastic bottles - CO2 emissions during their lifetime. https://timeforchange.org/plastic-bags-andplastic-bottles-co2-emissions-during-their-lifetime/

[26] Robert Gifford and Louise A. Comeau. 2011. Message framing influences perceived climate change competence, engagement, and behavioral intentions. Global Environmental Change 21, 4 (2011), 1301 - 1307. https://doi.org/10. 1016/j.gloenvcha.2011.06.004

[27] Mark R. Gleim, Jeffery S. Smith, Demetra Andrews, and J. Joseph Cronin. 2013. Against the Green: A Multi-method Examination of the Barriers to Green Consumption. Journal of Retailing 89, 1 (2013), 44 - 61. https://doi.org/10.1016/j. jretai.2012.10.001

[28] Yanne Goossens, Paulien Berrens, Lynn Charleer, Pieter Coremans, Melanie Houbrechts, Charlotte Vervaet, Johan De Tavernier, and Annemie Geeraerd. 2017. Qualitative assessment of eco-labels on fresh produce in Flanders (Belgium) highlights a potential intention-performance gap for the supply chain. Journal of Cleaner Production 140 (2017), 986 - 995. https://doi.org/10.1016/j.jclepro. 2016.05.063 Towards eco-efficient agriculture and food systems: selected papers addressing the global challenges for food systems, including those presented at the Conference "LCA for Feeding the planet and energy for life" (6-8 October 2015, Stresa \& Milan Expo, Italy).

[29] Klaus G. Grunert, Sophie Hieke, and Josephine Wills. 2014. Sustainability labels on food products: Consumer motivation, understanding and use. Food Policy 44 (2014), 177 - 189. https://doi.org/10.1016/j.foodpol.2013.12.001 
[30] Daniel Hanss. 2012. Explaining sustainable consumption. Findings from crosssectional and intervention approaches. (2012).

[31] Daniel Hanss and Rouven Doran. 2020. Perceived consumer effectiveness. Responsible Consumption and Production (2020), 535-544.

[32] Hanna Hartikainen, Taneli Roininen, Juha-Matti Katajajuuri, and Hannele Pulkkinen. 2014. Finnish consumer perceptions of carbon footprints and carbon labelling of food products. Journal of Cleaner Production 73 (2014), 285 - 293 https://doi.org/10.1016/j.jclepro.2013.09.018 Towards eco-efficient agriculture and food systems: Selected papers from the Life Cycle Assessment (LCA) Food Conference, 2012, in Saint Malo, France.

[33] Gerald Häubl and Valerie Trifts. 2000. Consumer Decision Making in Online Shopping Environments: The Effects of Interactive Decision Aids Marketing Science 19, 1 (2000), 4-21. https://doi.org/10.1287/mksc.19.1.4.15178 arXiv:https://doi.org/10.1287/mksc.19.1.4.15178

[34] Björn Hedin, Cecilia Katzeff, Elina Eriksson, and Daniel Pargman. 2019. A Systematic Review of Digital Behaviour Change Interventions for More Sustainable Food Consumption. Sustainability 11, 9 (2019). https://doi.org/10.3390/ su11092638

[35] Eric B. Hekler, Predrag Klasnja, Jon E. Froehlich, and Matthew P. Buman 2013. Mind the Theoretical Gap: Interpreting, Using, and Developing Behavioral Theory in HCI Research. In Proceedings of the SIGCHI Conference on Human Factors in Computing Systems (Paris, France) (CHI '13). Associ ation for Computing Machinery, New York, NY, USA, 3307-3316. https //doi.org/10.1145/2470654.2466452

[36] Eric B. Hekler, Predrag Klasnja, William T. Riley, Matthew P. Buman, Jennifer Huberty, Daniel E. Rivera, and Cesar A. Martin. 2016. Agile science: creating useful products for behavior change in the real world Translational Behavioral Medicine 6, 2 (02 2016), 317-328. https://doi org/10.1007/s13142-016-0395-7 arXiv:https://academic.oup.com/tbm/articlepdf/6/2/317/22066988/13142_2016_article_395.pdf

[37] Laura Henn, Oliver Taube, and Florian G. Kaiser. 2019. The role of environmental attitude in the efficacy of smart-meter-based feedback interventions. Journal of Environmental Psychology 63 (2019), 74 - 81. https://doi.org/10.1016/j.jenvp. 2019.04.007

[38] Gareth J Hollands, Ian Shemilt, Theresa M Marteau, Susan A Jebb, Michael P Kelly, Ryota Nakamura, Marc Suhrcke, and David Ogilvie. 2013. Altering microenvironments to change population health behaviour: towards an evidence base for choice architecture interventions. BMC public health 13, 1 (2013), 1-6.

[39] Pirjo Honkanen and James A Young. 2015. What determines British consumers motivation to buy sustainable seafood? British Food Journal (2015).

[40] Michael S. Horn, Pryce Davis, Aleata K. Hubbard, Danielle Keifert, Zeina Atrash Leong, and Izabel C. Olson. 2011. Learning Sustainability: Families, Learning, and next-Generation Eco-Feedback Technology. In Proceedings of the 10th International Conference on Interaction Design and Children (Ann $\mathrm{Ar}$ bor, Michigan) (IDC '11). Association for Computing Machinery, New York, NY, USA, 161-164. https://doi.org/10.1145/1999030.1999051

[41] Michael D. Kaplowitz and Ralph Levine. 2005. How environmental knowl edge measures up at a Big Ten university. Environmental Education Research 11, 2 (2005), 143-160. https://doi.org/10.1080/1350462042000338324 arXiv:https://doi.org/10.1080/1350462042000338324

[42] Paul M. Kellstedt, Sammy Zahran, and Arnold Vedlitz. 2008. Personal Efficacy, the Information Environment, and Attitudes Toward Global Warming and Climate Change in the United States. Risk Analysis 28, 1 (2008), 113-126. https://doi.org/10.1111/j.15396924.2008.01010.x arXiv:https://onlinelibrary.wiley.com/doi/pdf/10.1111/j.15396924.2008.01010.x

[43] Atsushi Kimura, Yuji Wada, Akiko Kamada, Tomohiro Masuda, Masako Okamoto, Sho ichi Goto, Daisuke Tsuzuki, Dongsheng Cai, Takashi Oka, and Ippeita Dan. 2010. Interactive effects of carbon footprint information and its accessibility on value and subjective qualities of food products. Appetite 55, 2 (2010), 271 - 278. https://doi.org/10.1016/j.appet.2010.06.013

[44] Predrag Klasnja, Sunny Consolvo, and Wanda Pratt. 2011. How to Evaluate Technologies for Health Behavior Change in HCI Research. In Proceedings of the SIGCHI Conference on Human Factors in Computing Systems (Vancouver, BC, Canada) (CHI '11). Association for Computing Machinery, New York, NY, USA, 3063-3072. https://doi.org/10.1145/1978942.1979396

[45] Verena Kurz. 2018. Nudging to reduce meat consumption: Immediate and persistent effects of an intervention at a university restaurant. Journal of Environmental Economics and Management 90 (2018), 317 - 341. https://doi. org/10.1016/j.jeem.2018.06.005

[46] Garrett Lentz, Sean Connelly, Miranda Mirosa, and Tim Jowett. 2018. Gauging attitudes and behaviours: Meat consumption and potential reduction. Appetite 127 (2018), 230 - 241. https://doi.org/10.1016/j.appet.2018.04.015

[47] Veranika Lim, Arvid Jense, Joes Janmaat, and Mathias Funk. 2014. EcoFeedback for Non-Consumption. In Proceedings of the 2014 ACM International Joint Conference on Pervasive and Ubiquitous Computing: Adjunct Publication (Seattle, Washington) (UbiComp '14 Adjunct). Association for Computing Machinery, New York, NY, USA, 99-102. https://doi.org/10.1145/2638728.2638772
[48] Ling Luo, Bin Li, Shlomo Berkovsky, Irena Koprinska, and Fang Chen. 2017. Online Engagement for a Healthier You: A Case Study of Web-Based Supermarket Health Program. In Proceedings of the 26th International Conference on World Wide Web Companion (Perth, Australia) (WWW '17 Companion). International World Wide Web Conferences Steering Committee, Republic and Canton of Geneva, CHE, 1053-1061. https://doi.org/10.1145/3041021.3055129

[49] Jennie I. Macdiarmid, Flora Douglas, and Jonina Campbell. 2016. Eating like there's no tomorrow: Public awareness of the environmental impact of food and reluctance to eat less meat as part of a sustainable diet. Appetite 96 (2016), 487 - 493. https://doi.org/10.1016/j.appet.2015.10.011

[50] Adriane Marie. 2018. Carbon Footprints of Foods List. https://healabel.com/ carbon-footprint-of-foods

[51] Doug McKenzie-Mohr and P. Wesley Schultz. 2014. Choosing Effective Behavior Change Tools. Social Marketing Quarterly 20, 1 (2014), 35-46. https://doi.org/ 10.1177/1524500413519257 arXiv:https://doi.org/10.1177/1524500413519257

[52] S Michie, M Johnston, C Abraham, R Lawton, D Parker, and A Walker. 2005. Making psychological theory useful for implementing evidence based practice: a consensus approach. BMJ Quality \& Safety 14, 1 (2005), 26-33. https://doi.org/10.1136/qshc.2004.011155 arXiv:https://qualitysafety.bmj.com/content/14/1/26.full.pdf

[53] Susan Michie, Maartje M Van Stralen, and Robert West. 2011. The behaviour change wheel: a new method for characterising and designing behaviour change interventions. Implementation science 6, 1 (2011), 42.

[54] Taciano L. Milfont. 2012. The Interplay Between Knowledge, Perceived Efficacy, and Concern About Global Warming and Climate Change: A One-Year Longitudinal Study. Risk Analysis 32, 6 (2012), 1003-1020. https://doi.org/10.1111/j.15396924.2012.01800.x arXiv:https://onlinelibrary.wiley.com/doi/pdf/10.1111/j.15396924.2012.01800.x

[55] Siwa Msangi, Mark W Rosegrant, et al. 2012. Feeding the future's changing diets: Implications for agriculture markets, nutrition, and policy. Edited by Shenggen Fan and Rajul Pandya-Lorch (2012), 65.

[56] Jaana-Piia Mäkiniemi and Annukka Vainio. 2014. Barriers to climate-friendly food choices among young adults in Finland. Appetite 74 (2014), 12 - 19. https://doi.org/10.1016/j.appet.2013.11.016

[57] Hung Vu Nguyen, Cuong Hung Nguyen, and Thoa Thi Bao Hoang. 2019. Green consumption: Closing the intention-behavior gap. Sustainable Development 27, 1 (2019), 118-129. https://doi.org/10.1002/sd.1875 arXiv:https://onlinelibrary.wiley.com/doi/pdf/10.1002/sd.1875

[58] The Vegetarian Society of the United Kingdom Limited. 2020. Seasonal UK grown produce. https://vegsoc.org/cookery-school/blog/seasonal-uk-grownproduce/

[59] Angela Peters-Texeira and Neela Badrie. 2005. Consumers' perception of food packaging in Trinidad, West Indies and its related impact on food choices. International Journal of Consumer Studies 29,6 (2005), 508-514. $\quad$ https://doi.org/10.1111/j.1470-6431.2005. 00419.x arXiv:https://onlinelibrary.wiley.com/doi/pdf/10.1111/j.14706431.2005.00419.x

[60] Petromil Petkov, Suparna Goswami, Felix Köbler, and Helmut Krcmar. 2012. Personalised Eco-Feedback as a Design Technique for Motivating Energy Saving Behaviour at Home. In Proceedings of the 7th Nordic Conference on Human-Computer Interaction: Making Sense Through Design (Copenhagen, Denmark) (NordiCHI '12). Association for Computing Machinery, New York, NY, USA, 587-596. https://doi.org/10.1145/2399016.2399106

[61] Brad Plumer. 2016. Study: Going vegetarian can cut your food carbon footprint in half. https://www.vox.com/2014/7/2/5865109/study-going-vegetarian-couldcut-your-food-carbon-footprint-in-half

[62] J. Poore and T. Nemecek. 2018. Reducing food's environmental impacts through producers and consumers. Science 360, 6392 (2018), 987-992. https://doi.org/10.1126/science.aaq0216 arXiv:https://science.sciencemag.org/content/360/6392/987.full.pdf

[63] Elena Claire Ricci, Alessandro Banterle, and Stefanella Stranieri. 2018. Trust to Go Green: An Exploration of Consumer Intentions for Eco-friendly Convenience Food. Ecological Economics 148 (2018), 54 - 65. https://doi.org/10.1016/j. ecolecon.2018.02.010

[64] Flanagan Logistics Warehouse Space. All rights reserved. 2017. How Is Food Transported? https://www.warehouse-space.co.uk/food-transport.html

[65] Tesco.com 2020 All rights reserved. 2020. Tesco Grocery. https://www.tesco. com/groceries/en-GB/

[66] Hannah Ritchie. 2017. Meat and Dairy Production. Our World in Data (2017). https://ourworldindata.org/meat-production.

[67] Sandra Rousseau and Liesbet Vranken. 2013. Green market expansion by reducing information asymmetries: Evidence for labeled organic food products. Food Policy 40 (2013), 31 - 43. https://doi.org/10.1016/j.foodpol.2013.01.006

[68] Elizabeth B-N Sanders. 2002. From user-centered to participatory design approaches. In Design and the social sciences. CRC Press, 18-25.

[69] Angela Sanguinetti, Kelsea Dombrovski, and Suhaila Sikand. 2018. Information, timing, and display: A design-behavior framework for improving the effectiveness of eco-feedback. Energy Research \& Social Science 39 (2018), 55 - 68. 
https://doi.org/10.1016/j.erss.2017.10.001

[70] Claudia R Schneider, Lisa Zaval, Elke U Weber, and Ezra M Markowitz. 2017. The influence of anticipated pride and guilt on pro-environmental decision making. PloS one 12, 11 (2017), e0188781.

[71] W3 Schools. 2020. Browser Statistics. https://www.w3schools.com/browsers/ default.asp

[72] Michael Schulte-Mecklenbeck, Matthias Sohn, Emanuel de Bellis, Nathalie Martin, and Ralph Hertwig. 2013. A lack of appetite for information and computation. Simple heuristics in food choice. Appetite 71 (2013), $242-251$ https://doi.org/10.1016/j.appet.2013.08.008

[73] Zero Waste Scotland. 2020. The carbon impacts of recycling and the effects of transport. https://www.zerowastescotland.org.uk/sites/default/files/Carbon\% 20impacts $\% 20$ of $\% 20$ recycling $\% 20$ and $\% 20$ transport.pdf

[74] Anne Sharp and Meagan Wheeler. 2013. Reducing householders' grocery carbon emissions: Carbon literacy and carbon label preferences. Australasian Marketing Journal (AMJ) 21, 4 (2013), 240 - 249. https://doi.org/10.1016/j ausmj.2013.08.004

[75] Sharon Shewmake, Abigail Okrent, Lanka Thabrew, and Michael Vandenbergh 2015. Predicting consumer demand responses to carbon labels. Ecological Economics 119 (2015), 168 - 180. https://doi.org/10.1016/j.ecolecon.2015.08.007

[76] Mical Kay Shilts, Marcel Horowitz, and Marilyn S. Townsend. 2004. Goal Setting as a Strategy for Dietary and Physical Activity Behavior Change: A Review of the Literature. American Journal of Health Promotion 19, 2 (2004), 81-93. https://doi.org/10.4278/0890-1171-19.2.81 arXiv:https://doi.org/10.4278/08901171-19.2.81 PMID: 15559708

[77] Alexa Spence and Nick Pidgeon. 2010. Framing and communicating climate change: The effects of distance and outcome frame manipulations. Global Environmental Change 20, 4 (2010), 656 - 667. https://doi.org/10.1016/j. gloenvcha.2010.07.002 20th Anniversary Special Issue.

[78] Marco Springmann, H. Charles J. Godfray, Mike Rayner, and Peter Scarborough. 2016. Analysis and valuation of the health and climate change cobenefits of dietary change. Proceedings of the National Academy of Sciences 113, 15 (2016), 4146-4151. https://doi.org/10.1073/pnas.1523119113 arXiv:https://www.pnas.org/content/113/15/4146.full.pdf

[79] Alain Starke, Martijn Willemsen, and Chris Snijders. 2017. Effective User Interface Designs to Increase Energy-Efficient Behavior in a Rasch-Based Energy Recommender System. In Proceedings of the Eleventh ACM Conference on Recommender Systems (Como, Italy) (RecSys '17). Association for Computing Machinery, New York, NY, USA, 65-73. https://doi.org/10.1145/3109859.3109902

[80] Carmen Tanner and Sybille Wölfing Kast. 2003. Promoting sustainable consumption: Determinants of green purchases by Swiss consumers. Psychology \& Marketing 20, 10 (2003), 883-902. https://doi.org/10.1002/mar.10101 arXiv:https://onlinelibrary.wiley.com/doi/pdf/10.1002/mar.10101

[81] Naundefineda Terzimehić, Christina Schneegass, and Heinrich Hußmann 2017. Exploring Challenges in Automated Just-In-Time Adaptive Food Choice Interventions. In Proceedings of the 2nd International Workshop on Multimedia for Personal Health and Health Care (Mountain View, California, USA) (MMHealth '17). Association for Computing Machinery, New York, NY, USA, 81-84. https://doi.org/10.1145/3132635.3132648

[82] Tesco.com. 2020. Sharwoods Green Label Mango Chutney 227G. https://www. tesco.com/groceries/en-GB/products/254865566

[83] Joël Thibert and Madhav G. Badami. 2011. Estimating and communicating food system impacts: A case study in Montreal, Quebec. Ecological Economics 70, 10 (2011), 1814 - 1821. https://doi.org/10.1016/j.ecolecon.2011.05.008

[84] Vanessa Thomas, Christian Remy, Mike Hazas, and Oliver Bates. 2017. HCI and Environmental Public Policy: Opportunities for Engagement. In Proceedings of the 2017 CHI Conference on Human Factors in Computing Systems (Denver, Colorado, USA) (CHI '17). Association for Computing Machinery, New York, NY, USA, 6986-6992. https://doi.org/10.1145/3025453.3025579

[85] John Thøgersen and Kristian S. Nielsen. 2016. A better carbon footprint label. Journal of Cleaner Production 125 (2016), 86 - 94. https://doi.org/10.1016/j. jclepro.2016.03.098

[86] Christina Tobler, Vivianne H.M. Visschers, and Michael Siegrist. 2011. Eating green. Consumers' willingness to adopt ecological food consumption behaviors. Appetite 57, 3 (2011), 674 - 682. https://doi.org/10.1016/j.appet.2011.08.010 Feeding infants and young children: guidelines, research and practice.

[87] Heather Barnes Truelove, Amanda R. Carrico, Elke U. Weber, Kaitlin Toner Raimi, and Michael P. Vandenbergh. 2014. Positive and negative spillover of pro-environmental behavior: An integrative review and theoretical framework. Global Environmental Change 29 (2014), 127 - 138. https://doi.org/10.1016/j gloenvcha.2014.09.004

[88] Mariëtte [van Amstel], Peter Driessen, and Pieter Glasbergen. 2008. Eco-labeling and information asymmetry: a comparison of five eco-labels in the Netherlands. Journal of Cleaner Production 16, 3 (2008), 263 - 276. https://doi.org/10.1016/j. jclepro.2006.07.039

[89] Ellen Van Kleef, Kai Otten, and Hans CM van Trijp. 2012. Healthy snacks at the checkout counter: A lab and field study on the impact of shelf arrangement and assortment structure on consumer choices. BMC public health 12, 1 (2012),
1072

[90] P Van Loon, AC McKinnon, L Deketele, and J Dewaele. 2014. The growth of online retailing: A review of its carbon impacts. Carbon Management 5, 3 (2014), 285-292.

[91] Jolien Vandenbroele, Hendrik Slabbinck, Anneleen Van Kerckhove, and Iris Vermeir. 2019. Mock meat in the butchery: Nudging consumers toward meat substitutes. Organizational Behavior and Human Decision Processes (2019). https://doi.org/10.1016/j.obhdp.2019.09.004

[92] Iris Vermeir and Wim Verbeke. 2006. Sustainable food consumption: Exploring the consumer "attitude-behavioral intention" gap. Journal of Agricultural and Environmental ethics 19, 2 (2006), 169-194.

[93] Iris Vermeir and Wim Verbeke. 2008. Sustainable food consumption among young adults in Belgium: Theory of planned behaviour and the role of confidence and values. Ecological Economics 64, 3 (2008), 542 - 553. https://doi.org/10. 1016/j.ecolecon.2007.03.007

[94] Desley Vine, Laurie Buys, and Peter Morris. 2013. The effectiveness of energy feedback for conservation and peak demand: A literature review. Open Journal of Energy Efficiency 2, 1 (2013), 7-15. https://doi.org/10.4236/ojee.2013.21002

[95] Pieter Vlaeminck, Ting Jiang, and Liesbet Vranken. 2014. Food labeling and eco-friendly consumption: Experimental evidence from a Belgian supermarket. Ecological Economics 108 (2014), 180 - 190. https://doi.org/10.1016/j.ecolecon. 2014.10.019

[96] Brian Wansink. 2015. Change Their Choice! Changing Behavior Using the CAN Approach and Activism Research. Psychology \& Marketing 32, 5 (2015), 486-500. https://doi.org/10.1002/mar.20794 arXiv:https://onlinelibrary.wiley.com/doi/pdf/10.1002/mar.20794

[97] E Owen D Waygood and Erel Avineri. 2011. Does" 500g of CO2 for a five mile trip" mean anything? Towards more effective presentation of $\mathrm{CO} 2$ information. In Proceedings of the Transportation Research Board 90th Annual Meeting. 2327.

[98] Fredrik Wikström, Helén Williams, Karli Verghese, and Stephen Clune. 2014. The influence of packaging attributes on consumer behaviour in food-packaging life cycle assessment studies - a neglected topic. Journal of Cleaner Production 73 (2014), 100 - 108. https://doi.org/10.1016/j.jclepro.2013.10.042 Towards eco-efficient agriculture and food systems: Selected papers from the Life Cycle Assessment (LCA) Food Conference, 2012, in Saint Malo, France.

[99] Rayoung Yang, Mark W. Newman, and Jodi Forlizzi. 2014. Making Sustainability Sustainable: Challenges in the Design of Eco-Interaction Technologies. In Proceedings of the SIGCHI Conference on Human Factors in Computing Systems (Toronto, Ontario, Canada) (CHI '14). Association for Computing Machinery, New York, NY, USA, 823-832. https://doi.org/10.1145/2556288.2557380

[100] William Young, Kumju Hwang, Seonaidh McDonald, and Caroline J. Oates. 2010. Sustainable consumption: green consumer behaviour when purchasing products. Sustainable Development 18, 1 (2010), 20-31. https://doi.org/10.1002/sd.394 arXiv:https://onlinelibrary.wiley.com/doi/pdf/10.1002/sd.394

[101] Jorge Luis Zapico, Cecilia Katzeff, Ulrica Bohné, and Rebecka Milestad. 2016. Eco-Feedback Visualization for Closing the Gap of Organic Food Consumption. In Proceedings of the 9th Nordic Conference on Human-Computer Interaction (Gothenburg, Sweden) (NordiCHI '16). Association for Computing Machinery, New York, NY, USA, Article 75, 9 pages. https://doi.org/10.1145/2971485.2971507 


\section{A APPENDIX A}

\begin{tabular}{|c|c|}
\hline Prompt & $\begin{array}{l}\text { Reputable } \\
\text { Source }\end{array}$ \\
\hline $\begin{array}{l}\text { Avoiding meat and dairy is the 'single biggest way' to reduce } \\
\text { your impact on earth. The biggest analysis to date reveals the } \\
\text { huge footprint of livestock - it provides just } 18 \% \text { of calories } \\
\text { but takes up } 83 \% \text { of farmland. }\end{array}$ & $\begin{array}{l}\text { The } \\
\text { Guardian } \\
\text { [7] }\end{array}$ \\
\hline $\begin{array}{l}\text { Choosing to eat lower on the food chain by eating less meat } \\
\text { can significantly lower your impact on the environment. } \\
\text { Reports suggest the amount of corn and grain needed to } \\
\text { support } 1 \text { cow could feed } 10-15 \text { people. People are mak- } \\
\text { ing dietary choices to reflect their feelings towards these } \\
\text { impacts. }\end{array}$ & $\begin{array}{l}\text { The Life } \\
\text { Impact } \\
{[50]}\end{array}$ \\
\hline $\begin{array}{l}\text { Choosing products with less plastic packaging can be even } \\
\text { greener than recycling. Recent research suggests only } 9 \% \\
\text { of plastic has ever been recycled and plastic films are very } \\
\text { difficult to recycle. }\end{array}$ & $\begin{array}{l}\text { The } \\
\text { Guardian } \\
{[22]}\end{array}$ \\
\hline $\begin{array}{l}\text { If you buy as much as you can that's grown or produced } \\
\text { locally, you can save a huge amount of energy on shipping } \\
\text { and can feel proud about the local alternatives you have } \\
\text { picked. }\end{array}$ & $\begin{array}{l}\text { Wired } \\
{[10]}\end{array}$ \\
\hline $\begin{array}{l}\text { There could be a } 49 \% \text { reduction in greenhouse gas emissions } \\
\text { from food production if we all reduced our meat intake. } \\
\text { Research showed that a plant-based diet is the most carbon } \\
\text { light (creating } 6.4 \text { pounds } \mathrm{CO}_{2} \text { per day), while a diet heavy } \\
\text { in meat is also the heaviest in carbon ( } 15.8 \text { pounds } \mathrm{CO}_{2} \text { per } \\
\text { day). }\end{array}$ & $\begin{array}{l}\text { Oxford } \\
\text { Uni- } \\
\text { versity } \\
\text { Library } \\
{[62]}\end{array}$ \\
\hline $\begin{array}{l}\text { The best meats to cut down on are from sheep and cows; the } \\
\text { animals that produce the most atmosphere-frying methane. } \\
\text { If every family in the UK swapped out a red meat based meal } \\
\text { for a plant-based alternative just once a week, the environ- } \\
\text { mental impact would be equivalent to taking } 16 \text { million cars } \\
\text { off the road. }\end{array}$ & Vox [61] \\
\hline
\end{tabular}

Table 3: Messages presented at the beginning of every shop.

\section{B APPENDIX B}

We will collect following demographics data: age, gender, level of education, employment status, income range (below / average / above UK income level for age group), living area (rural, city, suburban), number of adults in household, whether meals are home cooked, who the main cook is, who the main grocery shopper is, whether a specific diet is followed, reasons to follow that diet, and religious preferences.

\section{APPENDIX C}

\begin{tabular}{|c|c|}
\hline $\begin{array}{l}\text { Subjective Knowledge (Strongly Agree - } 5 \text {... Strongly Dis- } \\
\text { agree - 1) }\end{array}$ & $\mathrm{ce}$ \\
\hline $\begin{array}{l}\text { In general, I feel I know a great deal about environmental } \\
\text { issues and problems. }\end{array}$ & [41] \\
\hline $\begin{array}{l}\text { I have a great deal of knowledge about green products ((e.g. } \\
\text { energy-saving products, environmentally friendly foods, eco- } \\
\text { friendly house products). }\end{array}$ & [27] \\
\hline $\begin{array}{l}\text { I have a great deal of knowledge about environmentally } \\
\text { friendly foods. }\end{array}$ & [27] \\
\hline I consider myself an expert on environmentally friendly foods. & [27] \\
\hline $\begin{array}{l}\text { I generally know less than my friends about environmentally } \\
\text { friendly foods. }\end{array}$ & [27] \\
\hline Skills (Strongly Agree - 5 ... Strongly Disagree - 1) & \\
\hline $\begin{array}{l}\text { When grocery shopping I know how to judge the environmen- } \\
\text { tal impact of food items. }\end{array}$ & [20] \\
\hline $\begin{array}{l}\text { When grocery shopping I think I know enough about carbon } \\
\text { footprints to feel pretty confident when I make a purchase. }\end{array}$ & [20] \\
\hline $\begin{array}{l}\text { When grocery shopping I find it easy to choose environmen- } \\
\text { tally friendly foods. }\end{array}$ & [27] \\
\hline $\begin{array}{l}\text { When grocery shopping I can identify environmentally } \\
\text { friendly foods. }\end{array}$ & {$[27]$} \\
\hline $\begin{array}{l}\text { ry shopping I cannot distinguish between environ- } \\
\text { endly and harmful food products. }\end{array}$ & {$[80]$} \\
\hline $\begin{array}{l}\text { When grocery shopping I can find environmentally friendly } \\
\text { foods among other foods. }\end{array}$ & [27] \\
\hline $\begin{array}{l}\text { When grocery shopping I am aware of environmentally } \\
\text { friendly foods. }\end{array}$ & {$[27]$} \\
\hline $\begin{array}{l}\text { When grocery shopping I do know the difference between } \\
\text { environmentally friendly foods and standard foods. }\end{array}$ & {$[27]$} \\
\hline \multicolumn{2}{|l|}{$\begin{array}{l}\text { Beliefs about Consequences (Strongly Agree - } 5 \text {... Strongly } \\
\text { Disagree - 1) }\end{array}$} \\
\hline $\begin{array}{l}\text { I believe my actions have an influence on global warming and } \\
\text { climate change. }\end{array}$ & $\begin{array}{l}{[30,} \\
42]\end{array}$ \\
\hline $\begin{array}{l}\text { My green consumption behaviour can have a positive impact } \\
\text { on the environment. }\end{array}$ & $\begin{array}{l}{[30,} \\
42]\end{array}$ \\
\hline $\begin{array}{l}\text { It is worthwhile for the individual consumer to do something } \\
\text { about pollution. }\end{array}$ & {$[27]$} \\
\hline $\begin{array}{l}\text { When I buy products, I try to consider how my use of them } \\
\text { will affect the environment. }\end{array}$ & {$[27]$} \\
\hline $\begin{array}{l}\text { Since one person can have an effect on pollution, it makes a } \\
\text { difference what I do. }\end{array}$ & {$[27]$} \\
\hline \multicolumn{2}{|l|}{ Objective Knowledge (True \& False) } \\
\hline $\begin{array}{l}\text { Milk in plastic packaging is more harmful for the environment } \\
\text { than milk in cardboard cartons. }\end{array}$ & {$[80]$} \\
\hline $\begin{array}{l}\text { Less energy is used for meat production that for the equivalent } \\
\text { amount of vegetables. }\end{array}$ & {$[80]$} \\
\hline \multicolumn{2}{|l|}{ Intention (Strongly Agree - 5 ... Strongly Disagree - 1) } \\
\hline $\begin{array}{l}\text { I am willing to consider switching to other brands for ecological } \\
\text { reasons. }\end{array}$ & [57] \\
\hline $\begin{array}{l}\text { I will consider buying environmentally friendly foods because } \\
\text { they are less polluting. }\end{array}$ & {$[57]$} \\
\hline I plan to buy environmentally friendly foods in the next mon & \\
\hline
\end{tabular}

Table 4: Questions to assess knowledge, beliefs, and intentions. Participants will fill in this questionnaire pre and post study. 